\title{
Colonization of artificial substrata by teredinid larvae released from a previously infested focus at Ilha Grande Bay, RJ.
}

\author{
Ricardo Silva Varotto ${ }^{* 1}$ and Cristine Costa Barreto $^{2}$ \\ ${ }^{1,2}$ Departamento de Biologia Marinha, CCS, UFRJ, Cidade Universitária, Rio de Janeiro, RJ - 21949-900
}

\begin{abstract}
The colonization pattern of wooden panels by teredinid larvae released from a previously infested focus was investigated. Panels were placed at different distances $(1,10,20 \mathrm{~m})$ and in different directions from the focus. The colonization experiment took place at Parcel do Aleijado, Ilha Grande Bay, RJ. The focus remained immersed in nearly surface water, by the coast, during three months for infestation by teredinids. After this period, it was transferred to the study site. The infested focus and colonization panels remained in water, $10 \mathrm{~m}$ deep, for three months more. Total density and density of the dominant species were considered for each group of panels. Five teredinid species were found: Bankia fimbriatula, Bankia gouldi, Lyrodus floridanus, Lyrodus massa and Teredo furcifera. The dominant species was Teredo furcifera (76.6\%). Significant differences were only observed between directions for total teredinids and for dominant species density. Results concerning the dominant species Teredo furcifera were even more expressive and suggested the occurrence of a local water circulation pattern.
\end{abstract}

Keywords: Teredinidae, colonization, benthic ecology, dispersion

\section{INTRODUCTION}

Despite their fundamental ecological role in the decomposition of terrestrial vegetation, which naturally reaches the ocean, teredinid mollusks cause great damage to wooden structures constructed by man, in the marine environment. After settlement, the planktonic larva metamorphoses into a xylophagous adult, which begins to bore into the substrate. The larval period has also a great importance on the impact of teredinids in marine environments, given its relationship with dispersion. Benthic marine invertebrates are highly dependent on the action of water flow and current velocity for maintaining processes such as respiration, feeding, reproduction and dispersion (Judge \& Craig, 1997). Different studies have established that larval settlement is affected by current velocity, there existing a critical range for the effectiveness of this event. Although, recently, no study could be found referring to processes involving teredinids, some investigations have focused on the importance of currents to other marine invertebrates (Hunt \& Scheibling, 1996,

* Author for correspondence on the recruitment of Mytilus trossolus and M. edulis; Manuel et al., 1996, on the migration of Placopecten magellanicus; and Judge \& Craig, 1997, on the recruitment of Balanus eburneus). Besides the action of water currents, teredinids may guarantee their long distance dispersion through the infestation of wooden craft hulls or driftwood.

Unlike the majority of marine organisms, teredinids are almost entirely dependent on terrestrial primary production for their subsistence. Although the nitrogen content in their diet needs a complement from planktonic filtration, wood is the main source of carbohydrates for teredinids and their occurrence may be limited by wood supply, even if all other ecological requirements are satisfied. Studies previously developed along the southern coast of Brazil positively related the infestation of teredinids to the volume of wood available for colonization (Lavrado, 1986) and to the existence of artificial focuses of wood which may act as sources of larval release (Tiago, 1989). Silva (1985), investigating teredinid communities from Portogallo and 
Piraquara inlets, Ilha Grande Bay, affirmed that periods of higher colonization of artificial wooden collecting devices were more clearly related to the existence of focuses of larval release than to any alteration in abiotic conditions in the area. Such focuses are frequently constituted of fishing crafts or private ones that, given their motility, have their effect as larval sources extended to a great geographical range. Hence, the infestation of mobile substrates may generate a potential impact even in regions which, primarily, are not favorable to the occurrence of teredinids. The presence of great many wooden crafts in Ilha Grande Bay contributes to an increased volume of wood in the marine environment. Also, the bay is bounded by a mountain chain (Serra do Mar) which is densely recovered by rainforest, reaching peaks as high as $1000 \mathrm{~m}$, responsible for much of the wooden detritus reaching the water. Fouling organisms may act as a physical and biological barrier to the penetration of teredinid larvae and to the survival of adults in the substrate. Given the oligotrophic conditions of the water, the development of fouling organisms in the bay is greatly injured, making the environment extremely favorable for the development of teredinids (Barreto, 1993) and, hence, to the constitution of focuses of larval release and dispersion.

The better understanding of the patterns of dispersion and colonization of teredinid larvae is essential for a complete knowledge of the ecology of species and of great value in the establishment of more efficient infestation control techniques. Probably less than $10 \%$ of teredinid species are biologically known and few were studied in all phases of their life cycles (Turner, 1981). The little success obtained in controlling their activity is probably due to the fact that much more attention is given to protection methods than to the study of the organisms themselves. This is particularly true for tropical areas, where a great species richness and abundance of individuals make the study of teredinid populations especially relevant.

This study investigated the species composition and pattern of colonization of larvae of teredinids in wooden collecting devices placed near an artificial larval focus, previously infested, and immersed close to Parcel do Aleijado, Ilha Grande Bay, Rio de Janeiro. The hypothesis tested were: (1) a focus of larvae, $10 \mathrm{~m}$ deep, influences the colonization of recently immersed devices, placed at different distances from it; and (2) there is a greater recruitment associated to the main direction of the local water circulation, as evident by a differentiated pattern of infestation of recently immersed devices placed at different directions, around the focus.

\section{MATERIAL AND METHODS}

An artificial focus remained immersed near the coast (Enseada do Bonfim), 1m deep, for three months (Oct/94 to Jan/95) for infestation by teredinids. Following this stage, a second phase of the experiment took place at Parcel do Aleijado, Ilha Grande Bay (Figure 1).

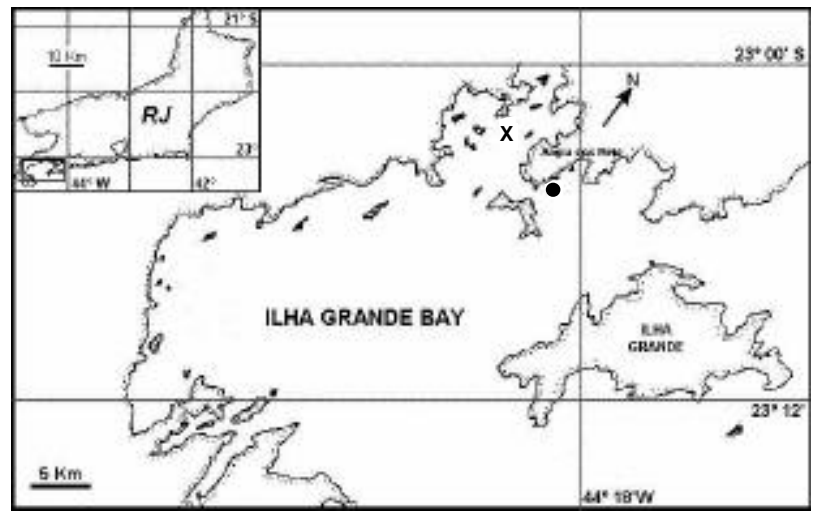

Fig. 1 - Study sites of infestation ( X ) and colonization $(\bullet$ ) periods.

The focus structure was made of 26 pinewood pieces (Araucaria angustifolia (Bertol) O. Kuntze), $0.60 \times 0.60 \times 0.03 \mathrm{~m}$ (Figure 2); held together by screws and nuts, in such a way that a good surface of wood for colonization was exposed in relation to the volume of the whole structure. The focus was transported to Parcel do Aleijado immediately after the infestation period was finished. Infestation time interval was based on information from previous studies developed in the area (Lavrado, 1986; Barreto, 1993; Silva, Martins-Silva, Laje \& Antunes, 1983, Junqueira, Omena \& Silva, 1991.). A three-month interval assured an expressive colonization of devices, enabling subsequent 
statistical analysis, but also avoided superpopulation, which might interfere in data interpretation.

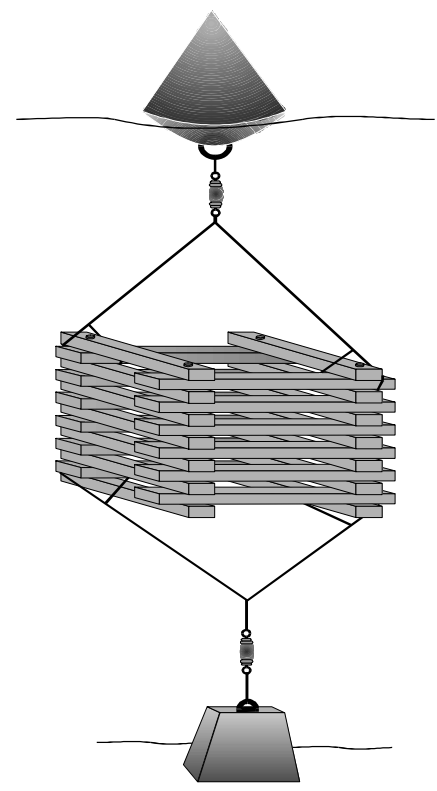

Fig. 2 - Focus structure.

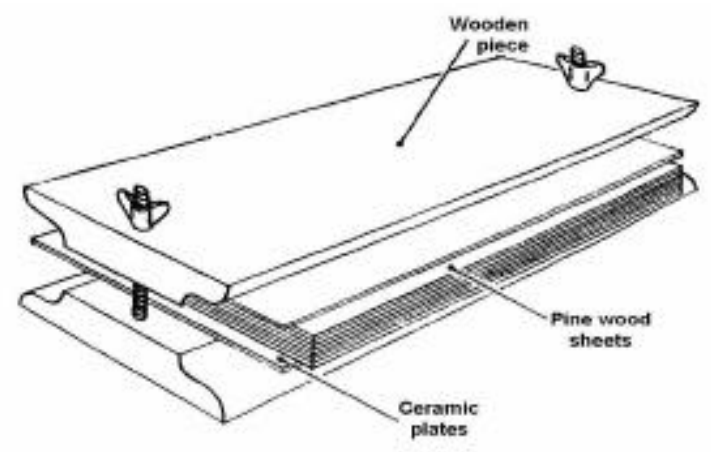

Fig. 3 - Collecting device.

For the colonization experiment, pine wood panels were used. Collecting devices consisted of 10 pine wood sheets, $100 \times 100 \times 8 \mathrm{~mm}$, set between two ceramic plates and two pieces of wood (Junqueira \& Silva, 1991, Figure 3). Five panels were vertically fixed to a PVC pipe, $15 \mathrm{~cm}$ apart, constituting a group. Along each of four directions, perpendicular to the focus (from now on referred to as arms), three groups of devices (G1, G2 and G3) were placed, at progressively longer distances from it $(1,10$ and $20 \mathrm{~m}$, respectively. Arms were denominated $\mathrm{A} 1, \mathrm{~A} 2, \mathrm{~A} 3$ and $\mathrm{A} 4$, according to the structure illustrated in Figure 4. The experimental design constituted, therefore, a five replicate experiment for each treatment (distance/direction). Both devices and infested focus were kept $10 \mathrm{~m}$ deep, for other three months (Jan/95-Abr/95), remaining approximately $1.5 \mathrm{~m}$ from the bottom.

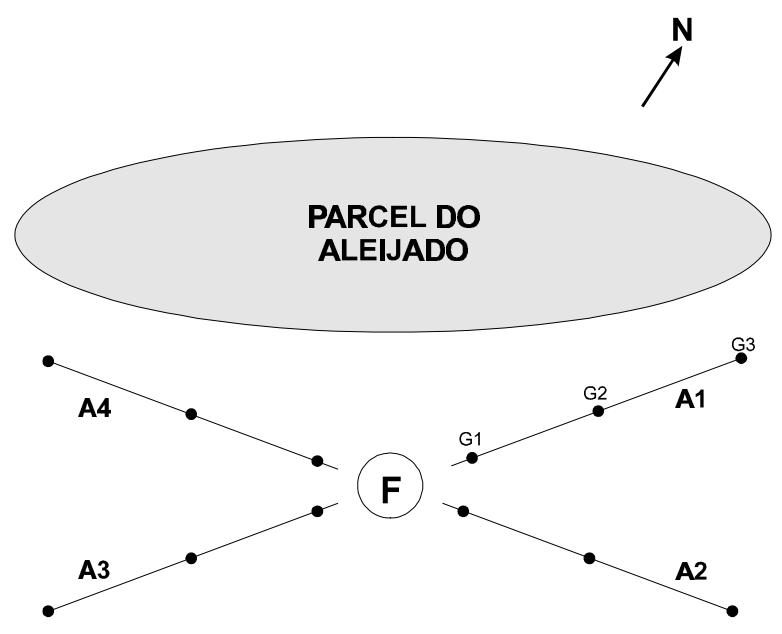

Fig. 4 - Position of arms (A1 to A4) and groups (G1 to G3) in relation tho the focus $(\mathrm{F})$ and to Parcel do Aleijado (real dimensions are not mantained).

Bartlett's test was used to verify the homocedasticity of variances and the need of transformation procedures in order to use parametric statistics. Variances were homocedastic, allowing the use of parametric tests with no previous transformation.

A two-way analysis of variance was considered in order to evaluate the variation of panels infestation in relation to their distance from the focus (G1, G2, and G3) and to the different directions (A1, A2, A3 and A4). Total density of teredinids and density of the dominant species were considered. Nevertheless, two treatments (A3G3 and A4G3) were lost due to weather conditions, unbalancing the experimental design. A two-way analysis of variance became, therefore, inadequate, and could only be used disregarding the third distance (G3), in order to generate a symmetrical design. A second, one-way, analysis was used for arms A3 e A4, separately, in order to access results referring to a complete set of distances. After the analysis, when necessary, Tukey's test was used in order to group treatments.

According to Valentin (1995), a correspondence analysis was used for ordenating groups of devices in relation to species composition and infestation. 
Table 1 - Average density - number of individuals per panel - and (standart deviation) of teredinid species present in the collecting devices. $\mathrm{G} 1, \mathrm{G} 2$ and $\mathrm{G} 3=$ groups 1 to 3 .

\begin{tabular}{l|ccc|cccc|ccccc}
\hline & \multicolumn{3}{|c}{ ARM 1 } & \multicolumn{3}{c|}{ ARM 2 } & \multicolumn{3}{c|}{ ARM 3 } & \multicolumn{2}{c}{ ARM 4 } \\
\cline { 2 - 11 } & G1 & G2 & G3 & G1 & G2 & G3 & G1 & G2 & G1 & G2 \\
\hline B. fimbriatula & 0.0 & 0.0 & 0.0 & 0.2 & 0.0 & 0.0 & 0.0 & 0.0 & 0.0 & 0.0 \\
& $(0.0)$ & $(0.0)$ & $(0.0)$ & $(0.4)$ & $(0.0)$ & $(0.0)$ & $(0.0)$ & $(0.0)$ & $(0.0)$ & $(0.0)$ \\
B. gouldi & 0.2 & 0.2 & 0.2 & 0.2 & 0.0 & 0.4 & 0.6 & 0.0 & 0.2 & 0.6 \\
& $(0.4)$ & $(0.4)$ & $(0.4)$ & $(0.4)$ & $(0.0)$ & $(0.5)$ & $(0.5)$ & $(0.0)$ & $(0.4)$ & $(0.8)$ \\
L. floridanus & 2.2 & 2.2 & 2.0 & 1.4 & 1.6 & 0.8 & 1.0 & 1.4 & 1.6 & 0.6 \\
& $(1.2)$ & $(1.2)$ & $(1.2)$ & $(1.2)$ & $(1.2)$ & $(1.2)$ & $(1.2)$ & $(1.2)$ & $(1.2)$ & $(1.2)$ \\
L. massa & 0.0 & 0.2 & 1.2 & 0.4 & 0.0 & 0.0 & 0.0 & 0.2 & 0.2 & 0.0 \\
& $(0.0)$ & $(0.4)$ & $(1.5)$ & $(0.5)$ & $(0.0)$ & $(0.0)$ & $(0.0)$ & $(0.4)$ & $(0.4)$ & $(0.0)$ \\
T. furcifera & 9.8 & 8.6 & 9.2 & 8.2 & 11.4 & 4.4 & 7.0 & 4.4 & 9.0 & 7.0 \\
& $(4.0)$ & $(1.4)$ & $(0.7)$ & $(1.2)$ & $(3.6)$ & $(1.0)$ & $(2.8)$ & $(2.4)$ & $(1.9)$ & $(1.7)$ \\
Non identified & 0.4 & 0.0 & 1.0 & 0.0 & 0.8 & 0.2 & 0.0 & 0.4 & 0.0 & 0.6 \\
& $(0.5)$ & $(0.0)$ & $(0.9)$ & $(0.0)$ & $(1.6)$ & $(0.4)$ & $(0.0)$ & $(0.8)$ & $(0.0)$ & $(0.8)$ \\
\hline TOTAL & 12.6 & 11.2 & 13.6 & 10.4 & 13.8 & 5.8 & 8.6 & 6.4 & 11.0 & 8.8 \\
& $(4.5)$ & $(2.4)$ & $(2.9)$ & $(1.4)$ & $(4.2)$ & $(0.7)$ & $(3.0)$ & $(3.5)$ & $(2.3)$ & $(1.0)$ \\
\hline
\end{tabular}

\section{RESULTS AND DISCUSSION}

\section{Specific Composition}

A total number of 484 individuals of teredinid mollusks were found inside the wooden panels, representing five species: Bankia fimbriatula (1 individual, 0.2\%), Bankia gouldi (13 ind., $2.7 \%$ ), Lyrodus floridanus (73 ind., 15.1\%), Lyrodus massa (10 ind., 2.1\%) and the largely dominant species: Teredo furcifera (371 ind., representing $76.6 \%$ of the total number of organisms inside the panels) (Table 1).

The dominance of $T$. furcifera was not in accordance to results obtained in previous studies, developed in Ilha Grande Bay, which revealed an expressive dominance of $L$. floridanus (Silva, 1985, Junqueira, Silva \& Martins-Silva, 1989; Omena, Junqueira \& Silva, 1990; Fernandes, 1989; Silva, Junqueira, Martins-Silva, Zalmon \& Lavrado, 1989) and, more recently, of B. gouldi (Barreto, 1993). The reasons for such differences are not clear, although factors related to particular characteristics of distinct regions of the bay where the studies took place may be involved. Also, a slow substitution of the dominant species along the years was to be considered together with aspects of the reproductive biology of species (T. furcifera and $L$. floridanus are larviparous, while $B$. gouldi is oviparous). Larviparous species should have a greater ability in colonizing panels closer to the focus, since their larvae are released in a late stage of development and may more readily bore into the wood. Oviparous species may remain in the plankton long enough to be dislodged from the intercept area of the devices. Hoagland and Turner (Hoagland \& Turner, 1981) found that larviparous species were the most successful invaders among teredinids, since the young remained in brooding pouches during the initial and more critical stages of development.

In the present study, differences in species composition seem to be closely related to the depth where panels were kept (10.0 meters). In studies mentioned above, devices were kept near the surface (1-2m deep), suggesting that a change in species composition, either quantitatively or qualitatively have been determined by depth. Depth may influence species composition since it interferes in factors such as salinity and temperature stratification, light intensity or the presence of fouling organisms. McKoy (1981) placed wooden panels at different depths, and noticed that, despite higher densities of teredinids were recorded for deeper panels, the species Lyrodus pedicellatus settled preferentially on those near the surface. Martins-Silva et al. (Martins-Silva, Silva \& Junqueira, 1988) also investigated teredinid colonization of pine wood panels along a depth gradient, in Ilha Grande Bay. Results obtained were opposed to those from 
McKoy (1981) in relation to total infestation, but authors also noticed a decrease in the colonization rate by $L$. floridanus with depth. Martins (1985), investigating teredinid communities at Forno Beach, Arraial do Cabo, northern coast of Rio de Janeiro, noticed that L.floridanus became less frequent as panels became closer to the bottom. According to McKoy (1981), the tendency of a higher infestation by $L$. floridanus nearer the surface resulted from the greater ability of long term larviparous species in colonizing floating wood, assuring a greater dispersion than the short free living existence of such larvae would allow. Such data suggested that the reason for the small density of L.floridanus in our panels and, indirectly, the dominance of $T$. furcifera in devices placed at a greater depth, was possibly related to a diminished exclusion effect by the former larviparous species.

The presence of B. gouldi was recorded in nearly all groups of devices, although in low densities (Table 1). The oviparous reproductive strategy of the species, probably made settlement in panels placed at relatively short distances from the focus less probable. The whole set of distances adopted in this study (1, 10 and $20 \mathrm{~m}$ ) were probably short enough to cause results mentioned above. The presence of other two species (B. fimbriatula and L. massa) was previously recorded for the area, and also in low densities (Silva, 1985; Barreto, 1993; Junqueira \& Silva, 1991; Junqueira, Silva \& Martins-Silva, 1989; Omena, Junqueira \& Silva, 1990; Fernandes, 1989, Silva, Junqueira, Martins-Silva, Zalmon \& Lavrado, 1989; , Martins-Silva, Silva \& Junqueira, 1988).

Only two axes were considered in the correspondence analysis, which were responsible for $79.0 \%$ of data variation. Because T. furcifera was dominant in all panels $(76.6 \%$ of the total number of individuals, Table 1), the species was not particularly linked to any of the three major groupings (I, II and II, Figure 5) evident in the ordination. Teredo furcifera remained near the origin of the axes, central to the groupings formed. For an opposite reason, B. fimbriatula also showed no link to any grouping, because of its low density $(0.2 \%$ of the total number of individuals, Table 1). Axes were probably not associated to abiotic factors such as depth, temperature, salinity or nutrients, for their conditions did not vary among devices. An expected segregation of groupings reflecting equivalent distances or directions was not evident. The three groupings seem to be strongly related to the density of the less numerous species (L. massa, B. gouldi and L. floridanus, respectively, Figure 5).

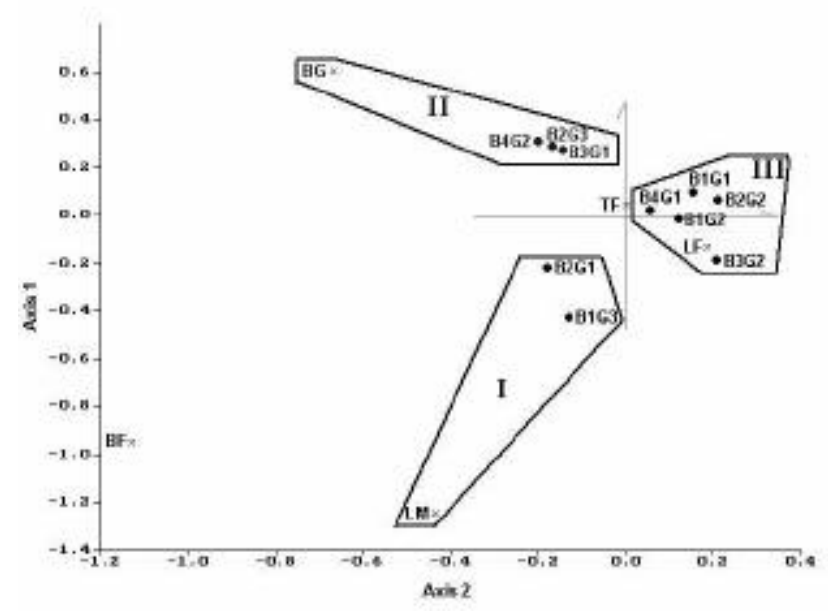

Fig. 5 - Graphic representation of correspondence analysis, revealing the position of groupings (I, II and III) of treatments in relation teredinid species. $\mathbf{B F}=\mathrm{B}$. fimbriatula, $\mathbf{B G}=\mathrm{B}$. gouldi, $\mathbf{L F}=$ L. floridanus, $\mathbf{L M}=\mathrm{L}$. massa, $\mathbf{T F}=\mathrm{T}$. furcifera .

\section{Effect of focus in relation to different distances}

Results reflected a small variation of infestation between devices placed at progressively longer distances from the focus. In the majority of the cases, this variation was not significant, both in relation to the total number of individuals or to the dominant species.

The fact that a clear pattern of colonization from the focus was not observed, may derive from the possibility that the distances adopted in this study were not long enough to lead to marked differences in terms of infestation. Too short distances might have caused a situation where abundant species would not reveal any pattern of dispersion and colonization. Silva (1985) showed that a single individual of L.floridanus, two-month old and $20 \mathrm{~mm}$ long might release 48000 larvae in an advanced stage of 
development, able to penetrate into the wood in a few time. In the present study, an extremely high number of larvae of $T$. furcifera colonized the wooden panels. Such an amount of larvae may have constituted a spray of colonizers enclosing, in an homogeneous way, all groups of devices positioned at each of the distances considered (Figure 6, white species). In this case, a pattern could be evident only through the infestation by less frequent species (Figure 6, black species). Nevertheless, no pattern was clear, for the less dominant species occurred in too low densities.

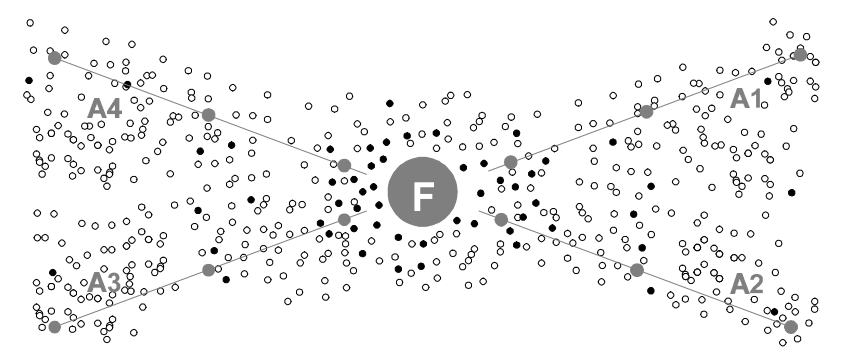

Fig. 6 - Hypothetic infestation pattern by larvae of two (white and black) teredinid species with different densities, released from the focus.

Tiago (1989) investigated the colonization of wooden collecting devices immersed in São Sebastião (northern coast of São Paulo), and noticed a strong increase in teredinid densities due to a substantial increase in the amount of wood which became available in the area. A concomitant study developed at the same site, for six months, made the volume of wood available for colonization 4.3 times higher $\left(1500\right.$ to $\left.6450 \mathrm{~cm}^{3}\right)$. In the present study, the time interval during which panels were exposed to infestation may have been too long, making each group of collecting devices turn into a small focus, exporting larvae to those at successively longer distances. This may explain the absence of an expected pattern where density should decrease towards those groups farther from the focus. Actually, in some cases, a greater infestation was recorded in groups more distant from it (A1G3 and A2G2). It is possible that observations carried out in time intervals inferior to three months might reveal some colonization pattern similar to the one mentioned above.

\section{Effect of focus in relation to different directions}

In general, arms A1 and A3 presented groups with the higher and lower number of teredinids, respectively; reflecting different patterns of colonization (ANOVA, $\mathrm{p}<0.10, \mathrm{p}=0.0762$ ) associated to the two different directions represented by these two arms.

Although information on the local patterns of current velocity was not investigated in situ, different intensities of infestation between these arms suggest the existence of some local pattern of water circulation, in the direction A3-A1, as illustrated in Figure 7. This supposition explains some of the patterns observed. A more intense water flow in this direction was in accordance to a higher infestation of arm A3 when compared to A1. On the other hand, A1 would not reveal an expected pattern of colonization due to the effect of the larval spray enclosing distances greater than those adopted in the study. The absence of any pattern associated to B2 and B4 was consonant with the existence of such a water flow carrying larvae in a perpendicular direction, which would not directly affect panels from those arms. Patterns of colonization, in this case, might be attributed to aleatory factors.

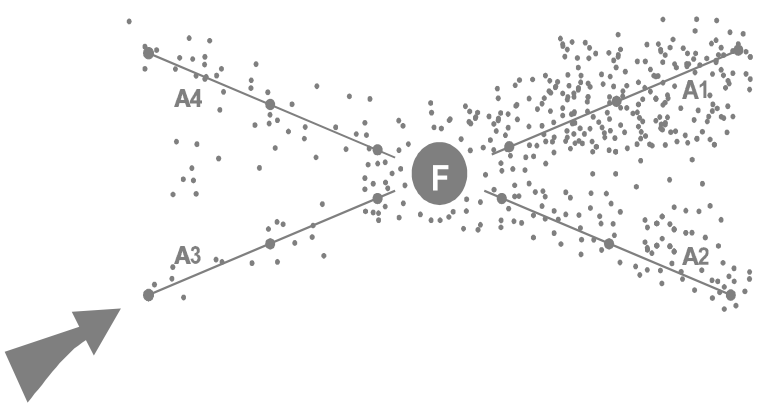

Fig. 7 - Water circulation pattern $(\rightarrow)$ suggested by results from panels infestation and consequences for larval dispersion from the focus.

The analysis of variance referring to the infestation by $T$. furcifera revealed some more expressive results, although the distribution of this species reflected that of the total population investigated. Significant differences were found between directions (ANOVA, $\mathrm{p}<0.05, \mathrm{p}=$ 0.0150 ) which were also pronounced by those existing between arms A1 and A3. 
Many authors related positively marine invertebrate recruitment to areas with a higher intensity of water currents. Judge and Craig (1997) experimentally controlled the intensity of water flow in one channel from an estuary in Long Island, New York. This was one of the few experiments available in the literature which investigated the role of water currents in situ. Recruitment of Balanus eburneus was five times higher than that naturally existing in the area when the current intensity suffered a twofold increase. Hunt and Scheibling (1996) observed the settlement rate of Mytilus edulis and $M$. trossolus in natural and artificial substrates in a rocky shore close to Halifax, Nova Scotia. Recruitment of mytilids was higher in substrates which were submitted to higher current intensity.

Ilha Grande Bay has been notorious for an intense infestation by teredinids; conditions for larval settlement being extremely (Silva, 1985; Barreto, 1993; Junqueira \& Silva, 1991; Junqueira, Silva \& Martins-Silva, 1989; Omena, Junqueira \& Silva, 1990; Fernandes, 1989, Silva, Junqueira, Martins-Silva, Zalmon \& Lavrado, 1989). In the present study, planktonic larvae already available in the area may have more readily colonized the devices than those still to be released by adults from the focus. In this case, the infestation of panels in relation, both to different distances and directions from the focus, might have been influenced.

Some of the questions which remained obscure, concerning the real influence of a larvae focus over the collecting devices used in this study, might be, at least partially, cleared out through the previous analysis of the local zooplankton, aiming to check the existence of teredinid larvae which might interfere in final results. This practice is not a simple one, since it is difficult to distinguish the veliger larva of teredinids from those which were released by other bivalve mollusks. The future use of techniques related to molecular systematics and to the precise determination of the origin (focus or plankton) of individuals in the devices appears as a valuable instrument in the analysis of the effect of focuses of dispersion of teredinid larvae along the oceanic provinces of the world. The importance of Ilha Grande Bay, in terms of the occurrence of teredinids and of the constitution of focuses of release and exportation of larvae of these organisms, has been once more reinforced.

The hypothesis that the focus of larvae influenced the colonization of wooden collecting devices immersed at progressive longer distances from it, was not confirmed, although some differences were observed in relation to the different directions, reinforcing the hypothesis of the existence of a local pattern of water circulation in the direction of arms A3A1.

The spatial variation of larval settlement of benthic marine invertebrates resulted from a combination of passive processes (hydrodynamic) and active ones (behavioral) acting in many different scales (Hunt \& Scheibling. 1996). Conclusive results concerning the recruitment of teredinids could not be accessed through the present experiment and subsequent studies are necessary for better understanding the forces structuring teredinid communities and for establishing real efficient infestation control methods.

Comparing to other organisms, teredinids are nowadays not exhaustively studied. A limited number of studies in this decade are available in the literature, difficultating the comparison of our results with those obtained by other researchers. A significant part of the coastal population in Brazil subsides from fishing activities and the costs involved in the prevention against the attack of wood boring organisms are not negligible. The greater the amount of information on the ecology and biology of these organisms, the higher would be the chances of achieving an optimum balance between the damage caused by wood boring activities and the benefits resulting from the decomposition of wood in the marine environment. 


\section{ACKNOWLEDGEMENTS}

We are greatly indebted to Professors Helena Passeri Lavrado, Paulo César Paiva and Andréa de Oliveira R. Junqueira for their suggestions and for the revision of this manuscript. We are also grateful to Professor Sérgio Henrique Gonçalves da Silva, for the methodological suggestions and for the logistic support during the field activities.

\section{RESUMO}

Foi estudado o padrão de colonização de larvas de teredinídeo liberadas a partir de um foco previamente infestado. Coletores foram posicionados a diferentes distâncias $(1 \mathrm{~m}, 10 \mathrm{~m}$, $20 \mathrm{~m}$ ) e em diferentes sentidos a partir do foco. $\mathrm{O}$ experimento de colonização foi realizado junto ao Parcel do Aleijado, Baía da Ilha Grande, RJ. O foco permaneceu imerso próximo à superfície, junto à costa, durante 3 meses para infestação por teredinídeos. Após este período, foi tranferido para a área de estudo. $\mathrm{O}$ foco infestado e os coletores permaneceram imersos, a $10 \mathrm{~m}$ de profundidade, por mais 3 meses. Foram consideradas a densidade total e a densidade da espécie dominante para cada grupo de coletores. Foram encontradas 5 espécies de teredinídeos: Bankia fimbriatula, Bankia gouldi, Lyrodus floridanus, Lyrodus massa and Teredo furcifera. A espécie dominante foi Teredo furcifera $(76,6 \%)$. Diferenças significativas foram observadas somente entre os diferentes sentidos, para o valor total de teredinídeos e para a densidade da espécie dominante. Os resultados envolvendo a espécie dominante Teredo furcifera foram ainda mais expressivos e sugerem a ocorrência de um padrão local de circulação de água.

\section{REFERENCES}

Barreto, C.C. 1993. Distribution of teredinids along the southeast coast of Brazil. Oebalia, vol XIX suppl., 155-162.

Fernandes, A.C. 1989. Influência de diferentes tipos de madeira na infestação e crescimento de moluscos da família Teredinidae
Rafinesque, 1815 (Mollusca: Bivalvia) na região da Baía da Ilha Grande, R.J. Graduation Monograph. Depto. de Biologia Marinha. Universidade Federal do Rio de Janeiro. $85 \mathrm{pp}$.

Hoagland, K.E. \& R.D. Turner. 1981. Evolution and adaptative radiation of wood-boring bivalves (Pholadacea). Malacologia, 21, 111148.

Hunt H.L. \& R.E. Scheibling. 1996. Physical and biological factors influencing mussel (Mytilus trossulus, M. edulis) settlement on a wave-exposed rocky shore. Marine Ecology Progress Series, 142, 135-145.

Judge, M.L. \& S.F. Craig. 1997. Positive flow dependence in the initial colonization of a fouling community: results from in situ water current manipulations. Journal of Experimental Marine Biology an Ecology, 210, 209-222.

Junqueira, A. O. R.; S. H. G. Silva \& M. J. Martins-Silva. 1989. Avaliação da infestação e diversidade de Teredinidae (Mollusca Bivalvia) ao longo da costa do Estado do Rio de Janeiro, Brasil. Mem.Inst. Oswaldo Cruz, 84, 275-280.

Junqueira, A.O.R. \& S.H.G. Silva. 1991. Estudo experimental dos Teredinidae Rafinesque, 1815 (Mollusca: Bivalvia) do estuário da Lagoa da Tijuca, Rio de Janeiro, R.J., Brasil. Rev. Brasil. Biol., 51(1), 113-116.

Junqueira, A.O.R., E.P. Omena \& S.H.G. Silva. 1991. A comparative study of the methods used to evaluate the activity of Teredinidae molluscs. J. Exp. Mar. Biol. Ecol., 150 (1), 113-116.

Lavrado, H.P. 1986. Influência da variação do volume de madeira na infestação e crescimento de Teredinidae (Mollusca:Bivalvia) na Região de Portogallo, R.J. Graduation Monograph. Depto. de Biologia Marinha. Universidade Federal do Rio de Janeiro. 52 pp.

Manuel J.L., S.M. Gallager, C.M. Pearce, D.A. Manning \& R.K. O`Dor. 1996. Veligers from different populations of sea scallop Placopecten magellanicus have different vertical migration patterns. Marine Ecology Progress Series, 142, 147-163.

Martins, L. C. A. 1985. Estudo preliminar sobre a distribuição vertical de organismos 
perfurantes de madeira na Praia do Forno, Arraial do Cabo - Rio de Janeiro. Graduation Monograph. Depto. Biologia Marinha. Universidade Federal do Rio de Janeiro. 27 pp.

Martins-Silva, M.J.; S.H.G. Silva \& A.O.R. Junqueira. 1988. Distribuição vertical de Teredinidae (Mollusca: Bivalvia) em Portogallo, Angra dos Reis, Rio de Janeiro, Brasil. Rev. Brasil. Zool., 5(1), 155-165.

McKoy, J.L. 1981. Vertical distribution of New Zealand shipworms (Bivalvia: Teredinidae). New Zealand Journal of Marine and Freshwater Research, 15, 403-409.

Omena, E.P.; A.O.R. Junqueira \& S.H.G. Silva. 1990. Resistência de Teredinidae Rafinesque, 1815 (Mollusca: Bivalvia) a diferentes períodos de exposição ao ar livre. Rev. Brasil. Biol., 50(3), 701-707.

Silva, S.H.G. 1985. Estudo experimental sobre a infestação de perfurantes marinhos na costa do estado do Rio de Janeiro. PhD Thesis. Fisiologia animal. Instituto de Biociências. Universidade de São Paulo. 231 pp.

Silva, S.H.G.; A.O.R. Junqueira; M.J. MartinsSilva; I.R. Zalmon \& H.P. Lavrado. 1989. Fouling and wood-boring communities distribution on the coast of Rio de Janeiro, Brazil. pp. 95-109. In: Coastlines of Brazil. Am. Soc. Civ. Eng., New York.
Silva, S.H.G.; M.J. Martins-Silva; W. Laje \& A.B. Antunes. 1983. Organismos marinhos perfurantes de madeira da região de Angra dos Reis. Proceeding from X Congresso Brasileiro de Zoologia. 59-60.

Tiago, C.G. 1989. Sobre uma comunidade de Teredinideos (Mollusca: Bivalvia) em São Sebastião (SP), Brasil. Master Thesis. Ecologia. Instituto de Biociências. Universidade de São Paulo. 88 pp.

Turner, R.D. 1981. "Wood islands" and "termal vents" as center of diverse communities in the deep sea. Biologia Morya, 1, 3-10.

Valentin, J.L. 1995. Agrupamento e ordenação, pp. 27-55. In: Oecologia Brasiliensis, Volume II: Tópicos em tratamento de dados. Peres-Neto, P.R.; Valentin, J.L. \& Fernandez, F.A.S. (eds). Programa de PósGraduação em Ecologia. Instituto de Biologia. Universidade Federal do Rio de Janeiro. 